\title{
A hierarchical indexation system: example of Emerillon (Teko)
}

\author{
Françoise Rose
}

\section{Introduction}

This chapter deals with the most challenging facet of the Emerillon language : the person indexation system. Its remarkable feature is the selection of the obligatory person index out of two series on transitive predicates. Transitive predicates allow only one person index, which is selected according to the relative position of the two arguments on both the person hierarchy $1 / 2>3$ and the grammatical roles hierarchy A $>$ P. I will argue that this system should be classified as a distinct type of indexation system, here termed 'hierarchical'.

Emerillon is a language spoken in French Guyana by about 400 speakers who call it Teko. It belongs to the Tupi-Guarani family (Rodrigues 1984-85), itself part of the Tupi stock. The Tupi-Guarani family consists of about 40 languages spread out through Brazil and neighbouring countries and "is noted for a high degree of lexical and morphological similarity among its member languages in spite of their extensive geographical separation" (Jensen 1999). Person-indexation, often called cross-referencing, is one of the major themes of Tupi-Guarani morphosyntax, which has been studied both within particular languages (Seki 1990 for Kamaiurá; Rodrigues 1990 for Tupinamba; Leite 1990 for Tapirapé; Harrison 1994 for Guajajara inter alia) and for the whole family (Jensen 1990; Payne 1994). As far as the Emerillon language is concerned, it was little described before my own work (Rose 2003, to appear). However, the question of person indexation in Emerillon had been presented before in an article on Emerillon parts of speech (Couchili, Maurel \& Queixalós 2002). The present work goes further into the description of the indexation system, and takes additionally a typological perspective.

The chapter first presents the Emerillon person indexation system on verbs $(\S 2)$. It will then discuss its characterization as a hierarchical system (§3) and reject the hypothesis that it is an inverse system. After considering these two points, I will address the issue of the alignment type to which 
Emerillon pertains. This study focuses specifically on the verb morphology and does not deal with nominal predication. ${ }^{1}$

\section{Indexation in Emerillon}

The person markers used on verbs are divided in two main sets, often called Set I and Set II in the Tupi-Guarani literature (Cf. for instance Jensen 1998).

Table 1. Emerillon sets of person indexes

\begin{tabular}{|c|c|c|}
\hline & Set I & Set II \\
\hline $1 \mathrm{SG}$ & $a-$ & $e-$ \\
\hline $2 \mathrm{SG}$ & ere- & $d e-$ \\
\hline $1 \mathrm{INCL}$ & $s i^{2}$ & nõde-/kõde- \\
\hline $1 \mathrm{EXCL}$ & oro- & ore- / orone- \\
\hline 2 PL & pe- & pe-/pene- \\
\hline 3 & $o-$ & $i-^{2} / \varnothing$ \\
\hline indeterminate & $z a-$ & zo- / poro- $^{3}$ \\
\hline
\end{tabular}

Set II indexes are also used outside of the verb morphology to refer to the possessor of nouns (1) and the object of postpositions (2).

(1) kob-ñ nõde-kuru-o

COP-CONTRAST 1INCL.II-manioc.beer-CONT

'But our traditional drink (manioc beer) still exists.'

(2) aRe-kom-âhã nõde-pekob

DEM-PL-only 1INCL.II-for COP

'These things only exist for us.' 
I will now explain their specific distribution on intransitive and transitive verbs. An important preliminary point is that all verb forms obligatorily carry a person index, regardless of whether arguments are expressed as full nominal phrases or not.

2.1. Intransitive verbs

On intransitive verbs, only Set I is found, referring to S.

(3) si-mãnõ-tar

1INCL.I-die-FUT ${ }^{4}$

'We are going to die.'

Intransitive predicates other than verbal ones will be presented in $\S 4$.

2.2. Transitive verbs

On transitive verbs, Set I is used for A and Set II for P.

Table 2. Distribution of person indexes on transitive verbs

\begin{tabular}{|l|c|c|}
\cline { 2 - 3 } \multicolumn{1}{c|}{} & $\mathrm{A}$ & $\mathrm{P}$ \\
\hline Set I & $\mathrm{x}$ & \\
\hline Set & & $\mathrm{x}$ \\
II & & \\
\hline
\end{tabular}

The interesting point about indexation on transitive verbs is that only one slot is normally available for person indexes. Whether the A or the P is marked depends on two different hierarchies. These hierarchies will be introduced when relevant in the following presentation of the three transitive scenarios : local (involving speech act participants only), non-local (involving third persons only) and mixed (involving a speech act participant and a third person). 


\subsubsection{Mixed scenarios}

Whenever a speech act participant and a third person interact, the person hierarchy is called into play. Speech act participants are higher than the third person on this scale.

Figure 1. Person hierarchy

$$
1 / 2>3
$$

The participant higher on the hierarchy is marked on the verb, whether A or P. In both examples below, a first person inclusive and a third person are involved. The first person being higher in the hierarchy, it is in both cases the one to fill the person index slot, with a Set I index when it is A (4), with a Set II index when it is P (5).

(4) nõde-ba Rek ${ }^{w}$ r-a-we si-kuwa-gatu

1INCL.II-story-REF-also 1INCL.I-know-well

'And we also know our story very well.'

(5) apam-a-n $\tilde{e}$

nõde-apisi-tanẽ

stranger-a-CONTRAST 1INCL.II-massacre-DESID

'The strangers wanted to massacre us.'

Likewise, in both examples below, a second person singular and a third person are involved. The second person being higher in the hierarchy, it is the one to be indexed on the verb, with a Set I index when it is A (6), with a Set II index when it is P (7).

$\begin{array}{ll}\text { mama-nẽ } & \text { ere-çika! } \\ \text { Mum-CONTRAST } & \text { 2SG.I-kill } \\ \text { 'You killed Mum!' } & \end{array}$

(7) $\boldsymbol{e}$-?u-tar-e?e

zawar.

2SG.II-eat-FUT-INTENS jaguar

'The jaguar is for sure going to eat me.' 
In all those cases, the indexing of a speech act participant on the verb, whether as A or P, indicates indirectly that the other participant, i.e. P or A, is to be interpreted as a third person.

\subsubsection{Non-local scenarios}

The person hierarchy does not specify any hierarchy between different third persons nor among speech act participants. The second hierarchy is the grammatical roles hierarchy, at work whenever the person hierarchy is not relevant, i.e. between two third persons or two speech act participants.

Figure 2. Grammatical roles hierarchy

$$
\mathrm{A}>\mathrm{P}
$$

When a third person acts on another third person, the grammatical roles hierarchy induces that it is the A that is systematically marked (with a Set I index), whatever the arguments may refer to.

(8)

$$
o-w \dot{0} \quad \boldsymbol{o} \text {-zika. }
$$

3.COREF-mother 3.I-kill

'He killed his mother.'

(9)

$\begin{array}{ll}\text { patu-pope } & \text { o-ipuy } \\ \text { pot-in } & \text { 3.I-put }\end{array}$

'She puts them (the sweet potatoes) in the pot.'

(10) arakapusa-uhu o-mõdur-oワ bal

gun-big 3.I-send-PL.S bullet

'Guns were shooting bullets.'
(11) o-pero-perog
$e-i b a$
$\varnothing$-owa
3.I-RED-lick
3.II-pet
3.II-face

'His dog licks his face.'

The $o$ - prefix of Set I (marking either Ss or As) here indicates indirectly that $\mathrm{P}$ is also a third person: if $\mathrm{P}$ was a speech act participant, it would have to occupy the index slot instead of A due to its higher position on the per- 
son hierarchy. A consequence of these two hierarchies is that the $i$ - prefix of Set II never occurs on verbs. ${ }^{5}$ It is nevertheless used in nominal phrases (as a possessive marker) and in postpositional phrases.

\subsubsection{Local scenario $2 \rightarrow 1$}

In Emerillon, the local scenarios (i.e. when the two participants are speechact participants, either $2 \rightarrow 1$ or $1 \rightarrow 2$ ) all show the A indexed on the verb, regardless of the person of the participants. The two local scenarios are therefore described as following the grammatical roles hierarchy $\mathrm{A}>\mathrm{P}$ already mentioned for the non-local scenario.

Table 3 presents the four instances where a second person (singular or plural) acts on a first person (singular or exclusive). In each case, A is marked with Set I on the verb, a pronoun follows the verb (the meaning of which is discussed below).

Table 3. $2 \rightarrow 1$ examples in Emerillon ${ }^{6}$

\begin{tabular}{|c|c|c|c|}
\hline A & $P$ & & \\
\hline $2 \mathrm{SG}$ & $1 \mathrm{SG}$ & $\begin{array}{l}\text { ere-nupã } \\
\text { 2sG.I-hit } \\
\text { 'You (SG) hit me }\end{array}$ & $\begin{array}{l}\text { eren } \\
2 \text { SG } \\
\text { e. }\end{array}$ \\
\hline $2 \mathrm{SG}$ & $1 \mathrm{EXCL}$ & $\begin{array}{l}\text { ere-nupã } \\
\text { 2SG.I-hit } \\
\text { 'You (SG) hit us. }\end{array}$ & $\begin{array}{l}\text { orone-kom } \\
\text { 1EXCL.II-PL } \\
\end{array}$ \\
\hline $2 \mathrm{PL}$ & $1 \mathrm{SG}$ & $\begin{array}{l}\text { pe-nupã } \\
\text { 2PL.I-hit } \\
\text { 'You (PL) hit me }\end{array}$ & $\begin{array}{l}\text { pen } \\
2 \text { PL } \\
\text { e. }\end{array}$ \\
\hline $2 \mathrm{PL}$ & 1EXCL & $\begin{array}{l}\text { pe-nupã } \\
\text { 2PL.I-hit } \\
\text { 'You (PL) hit us. }\end{array}$ & $\begin{array}{l}\text { orone-kom } \\
\text { 1EXCL.II-PL } \\
\therefore\end{array}$ \\
\hline
\end{tabular}

The presence of the independent pronominal form is necessary to disambiguate the $2 \rightarrow 1$ configuration with the configuration where a second person acts on a third person as in (12).

(12) еге-пира̃

2SG.I-hit

'You (SG) hit him/her/it/them.' 
Since when $2 \rightarrow 1$, A is systematically marked on the verb by a Set I prefix, we would expect the pronoun following the verb to refer to $\mathrm{P}$, but this is not always the case. In the second and fourth line of Table 3, oronekom, the normal free pronoun for first person exclusive, refers explicitly to $\mathrm{P}$, as expected. Surprisingly, in the first and third line, the independent forms ere $\mu$ and pep, used only in this specific scenario, are linked to second person pronominal forms rather than to first persons (Proto-Tupi-Guarani pronouns for second person singular and plural are reconstructed as *eré/ene and *pe...e, Jensen 1998). The system seems a priori illogical in synchrony: in order to refer to a second person A and a first person $\mathrm{P}$, two markers for second person are used. The oddity of the marking of $2 \mathrm{SG} / \mathrm{PL}$ $\rightarrow 1 \mathrm{SG}$ can be explained as a residue of a former $1>2$ hierarchy, substituted by the grammatical roles hierarchy $\mathrm{A}>\mathrm{P} .^{7}$

\subsubsection{Local scenario $1 \rightarrow 2$}

When a first person acts on a second person, Emerillon uses two different structures according to the number of P. oro- is used when a first person (singular or plural) acts on a second person singular (13), and a-poro- when a first person (singular or plural) acts on a second person plural (14).

\section{(13) oro-?u-tar}

1EXCL.I-eat-FUT

a- 'I will eat you. (and also: 'We will eat you')

b- 'We will eat it/her/him/them'

(14) a-poro-nupã-tar

1SG.I-INDET.II-hit-FUT

'I/we will hit you all (Lit. I hit people. In the text, told by a Dad furious at his misbehaving daughters).'

The use of oro- in (13) is ambiguous. As a Set I marker for first person exclusive (Cf. Table 1), it can refer to scenario b- where a first person exclusive acts on a third person, but it can also refer to the local scenario a-, i.e. a first person (singular or exclusive) acting on a second person singular. Following this, when a transitive verb is prefixed with a Set I first person exclusive marker, this marker refers to a first person $\mathrm{A}$, and $\mathrm{P}$ is inferred. In absence of any NP referring to P, only context can solve the ambiguity 
between a second and a third person P. Interestingly, with a second person $\mathrm{P}$, oro- neutralizes the number opposition of $\mathrm{A}$.

Indexation in (14) is made up of two morphemes: $a$ - first person singular of Set I (here neutralized in terms of number), referring to an A, and poro- usually referring to a generic human $\mathrm{P}$ (Cf. Table 1 ). The opaque encoding of the local scenarios (due to substitution of forms or semantic neutralization) has been discussed in a comparative and historical perspective and with reference to politeness (in line with Brown and Levinson 1987) in some former works (Rose 2003a, 2003b).

In summary, my analysis of the Emerillon local scenarios is as follows:

- For $2 \rightarrow 1$, A has priority to fill the index slot on the verb. The second person marker, following the verb, refers to $\mathrm{P}$ either directly (oronekom), or indirectly (eren, pen).

- For $1 \rightarrow 2 \mathrm{SG}$, oro- is analyzed as an A marker.

- For $1 \rightarrow 2 \mathrm{PL}, \mathrm{A}$ is marked with Set I $(a-)$, whereas $\mathrm{P}$ is marked with a human generic object (poro-).

My conclusion is that there is no obvious person hierarchy between the two speech act participants. The various local scenarios are better explained with the grammatical roles hierarchy already used for non-local scenarios than with any possible person hierarchy. Indeed, in all cases, A is indexed on the verb with Set I, while $\mathrm{P}$ is either unexpressed or expressed in a rather marginal way, i.e. as in 'incorporated' generic noun, or as a pronoun following the verb, sometimes actually referring to the person of the A.

The main points of the indexation system on Emerillon verbs are repeated below.

- On intransitive verbs, $\mathrm{S}$ is marked with Set I.

- On transitive verbs, either A or P are marked (with Set I and II respectively) according to their relative position on a person hierarchy or on a grammatical roles hierarchy. The $1 / 2>3$ person hierarchy operates when only one speech act participant is involved, and the $\mathrm{A}>\mathrm{P}$ grammatical hierarchy elsewhere.

The following section focuses on the use and organization of the different hierarchies operating in the Emerillon transitive constructions. Let's note for the sake of the coming discussion that the indexation system presented below is quite comparable to the indexation system of the independent clauses in other Tupi-Guarani languages, although differences can be noted in the local scenarios (cf. Rose 2007). In Emerillon, the same system also applies in dependent clauses. 


\section{Characterization of the hierarchical indexation system}

The terms "person hierarchy" and "grammatical roles hierarchy" used here correspond roughly to other designations that emerged in line with Silverstein's pioneer work on hierarchies of features (Silverstein 1976). The author highlighted the role of semantic properties of nominals on casemarking and agreement (more specifically in the domain of ergative or split-ergative systems). A recent label that subsumes all aspects (semantic, referential, discursive) of these hierarchies is for instance "Indexability Hierarchy" (Bickel and Nichols 2007: 224-227).

The two hierarchies used in Emerillon could logically be justified in terms of saliency, the most salient participant being put forward. It is nevertheless important to assert that this system is completely grammaticalized: whatever the characteristics of the participants are, what counts in the system is the grammatical persons and the grammatical roles.

While the person hierarchy which is attested in most Tupi-Guarani languages is usually presented as $1>2>3$, the Emerillon data points only at a $1 / 2>3$ hierarchy in a clear fashion. The reorganization of the person hierarchy (cf. endnote 6), more precisely the neutralization of the hierarchy between first and second persons, can be explained by politeness, just like the substitution patterns detailed in the local scenarios. This is tightly correlated to the fact that languages disfavour transparent marking of first and second person combinations (Heath 1998). This assertion is confirmed by the fact that both in Emerillon $(1 / 2>3)$ and in the hypothetic Proto-TupiGuarani $(1>2>3)$, the marking is very clear and systematic when only one speech act participant is involved, but less so when both first and second person are involved (Montserrat and Soares 1983). This difference of treatment is frequent in languages involving a person hierarchy. A similar example is given by Gildea (1994) in the inverse system of Caribe. DeLancey (no date) proposes the deictic nature of inverse and hierarchical systems as an explanation for the fact that these systems give a special status to speech act participants. The facts of Emerillon lead us to reconsider the 1>2>3 Tupi-Guarani hierarchy, at least as far as Emerillon is concerned. Once again, it is typologically common that a person hierarchy is clearly distinct with respect to $1>3$ and $2>3$ but less so when both speech act participants are involved. Even in a typological perspective, first and second person are independent within the hierarchy, their relative order fluctuates from one language to the other (Silverstein 1976, DeLancey 1981). This may help account for the fact that the Emerillon language suc- 
ceeded in reorganizing the Proto-Tupi-Guarani hierarchy concerning specifically the local scenario, neutralizing the hierarchy between the speech act participants. The grammatical roles hierarchy came into play to compensate this loss.

On transitive verbs, the correct index is selected according to the relative position of the two arguments on both the person hierarchy $1 / 2>3$ and the grammatical roles hierarchy $\mathrm{A}>\mathrm{P}$. Two hierarchies are involved, and Couchili, Maurel \& Queixalós (2002) propose to order them as follows.

$$
1 / 2>3 \text { person hierarchy } \quad>\quad \mathrm{A}>\mathrm{P} \text { hierarchy }
$$

Figure 3. Hierarchy of hierarchies

However, the authors consider that the person hierarchy is $2>1>3$, and therefore the grammatical roles hierarchy is used only when both participants are third persons. The present analysis describes the person hierarchy as $1 / 2>3$ and extends the scope of the grammatical roles hierarchy to the local scenarios: it is also outside the scope of the person hierarchy, and thus obeys the grammatical roles hierarchy. On the whole, the grammatical roles hierarchy becomes relevant when, and only when, the person hierarchy is not. I argue that this type of indexation system should be classified as hierarchical, as the primary organizing pattern is the notion of hierarchy. ${ }^{8}$

A first explicit definition of hierarchical systems considered on a par with neutral, accusative, ergative, stative-active and three-way systems, is Nichols (1992). Section 4 will discuss further developments of this definition, in relation with the question of alignment type.

"Access to inflectional slots for subject and/or object is based on person, number, and/or animacy rather than (or no less than) on syntactic relations" (Nichols 1992: 66).

Languages identified as displaying a hierarchical system are Cree, Tepehua, Mixe, Nunggubuyu, Kiowa (Nichols 1992), Tangut and some TibetoBurman languages (DeLancey 2001).

Since the existence of such person hierarchy in Tupi-Guarani languages has led to the interpretation of these agreement systems as inverse systems, I now turn to this interesting question. 


\section{Against the inverse hypothesis}

It was Doris Payne (1994) who first formulated the hypothesis that TupiGuarani languages could be described as having an inverse system. The author follows Givón's definition of the inverse, based on the notion of an "inherent topicality hierarchy" $1>2>3$ (Givón 1994). If $1 \rightarrow 2 / 3$ or $2 \rightarrow 3$, the action flows in the natural direction (A is more topical than $\mathrm{P}$ ). This is considered to be direct. If the action flows the other way around (when $\mathrm{P}$ is more topical than A), that is considered to be inverse. Further more, a canonical inverse language is a language that expresses the inverse direction with morphosyntactic devices in a transitive construction. Examples from Fox, an Algonquian language are repeated below (from Comrie 1981:122), where $-a a$ is a direct marker (15), and -ek an inverse one (16).

(15) ne-waapam-aa-wa

1SG-See-DIRECT-3

'I see him.'

(16) ne-waapam-ek-wa

1SG-See-INVERSE-3

'He sees me.'

D. Payne applies this definition to the Tupi-Guarani system, organized around a $1>2>3$ hierarchy. Direct situations are marked with Set I for A. They include some mixed scenarios (when $\mathrm{A}$ is superior to $\mathrm{P}$ on the person hierarchy) and the non-local scenario since when two third persons are involved, Set I is also used. Inverse situations are marked with Set II for P, and consist of the remaining mixed scenarios (when $\mathrm{P}$ is superior to $\mathrm{A}$ on the person hierarchy). The encoding of the local scenarios is not explicitly classified as direct or inverse. ${ }^{9}$ The author's main argument is that the relational $r$-prefix, found in co-occurrence with Set II, be analysed as an inverse marker in Tupi-Guarani languages. There would be no specific marker for direct. Following this analysis, the example (17) below would be a direct construction, with a Set I index for first person A and no index for P. Example (18) would be an inverse construction, with no index for A but a Set II index referring to first person P, and an overt inverse marker $r$ (these Wayampi examples are repeated from Payne 1990: 314-315). This hypothesis could be applied as it is to Emerillon, since the indexation sys- 
tem on independent verbs diverges with the rest of the family only in local scenarios.

(17) пати $\quad r-a^{\prime} y \quad j \tilde{l} \quad \boldsymbol{a}$-juka. tinamou LK-immature only 1SG.I-kill 'I killed just a little tinamou.'
(18) $\boldsymbol{e}$-r-aty-pa
$e-k e$
pe e-r-uwy
1SG.II-LK-cover-COMPLE 1SG.II-sleep in 1SG.II-LK-blood
'My blood completely covered me in my dream.'

However, a canonical inverse language is a language that expresses the inverse direction with an explicit morphosyntactic device. The relational morpheme that Payne suggests is an inverse marker in Tupi-Guarani languages (the $r$-relational) is found throughout the family on a lexically defined sub-class of transitive roots, but as well on certain intransitive roots, certain nouns and postpositions when preceded with a Set II index or a full object/possessor (see for example the second occurrence of $r$ - in example (18)). My first counter-argument is that its syntactic distribution is by far larger than the function of the inverse category. It could reasonably be glossed as "inverse marker" only on transitive roots. This analysis would not account for the unique function to be found throughout its distribution : the linking of a root with an immediately preceding complement (be it the $\mathrm{P}$ of a verb, the possessor or genitive of a noun or the object of a postposition). My second counter-argument is that it is found only with certain lexically determined roots. Its absence of some other roots (in (5) and (7) for instance) is an evidence that it is not essential to the system. Moreover, when present, it is redundant with the presence of Set II indexes, which are sufficient to refer to the whole participant scenario. In languages like Fox (illustrated in (15) and (16)), the inverse marker is obviously necessary to sort out which of the two participants is A and which is P. I therefore consider that no morpheme can be interpreted as an inverse marker in TupiGuarani languages. As a consequence, to make the inverse analysis possible in this language family, one should be willing to consider the sheer distribution of person markers into two sets as an inverse system. This assumption would be possible with a purely functional definition of inverse like those of Givón (1994) or Klaiman (1991) which find inverse whenever $\mathrm{P}$ is more topical than A, but A is still topical. This is actually what $\mathrm{T}$. 
Payne entitles "special verb agreement markers for inverse situations", citing data from Wayampi, a close relative of Emerillon (Payne 1997).

Therefore, if the Tupi-Guarani indexation system, and the Emerillon system in particular, was to be described as an inverse system, it would not be a canonical inverse in relation to the prototype of inverse (the Algonquian languages). First, direction of action is not expressed by a specific morpheme since no morpheme can be interpreted as an inverse marker. Second, it is not a complete system, since the non-local scenario and the local scenarios are not concerned. It is limited to the mixed scenarios, since a hierarchy would be lacking for the other scenarios. Therefore, although one can easily identify a function related to inverse in Tupi-Guarani languages, it is an insufficient argument to speak in terms of an inverse system. Positing person and grammatical roles hierarchies is sufficient to explain the indexation system.

This argument actually boils down to the confrontation between two different approaches. In the functional approach, inverse is to be found whenever P is more topical than A, but A is still topical (Givón 1994). In the syntactic approach, hierarchical indexation and the marking of direction (inverse) are independent (DeLancey 2001).

"Hierarchical alignment and direction are logically independent features that can, but need not, co-occur. A particular language may display verbal morphology that can be meaningfully described with the concept of hierarchical alignment alone, without there being direction marking. Similarly, the morphosyntax of a certain language may (i) be adequately described with a simple SAO model but (ii) allow for additional direction marking if there is no hierarchical alignment." (Zúñiga 2006:28)

The so-called inverse systems are then considered a particular case of hierarchical systems (Nichols 1992, Siewierska 2004) or for DeLancey, both are expressions of the deictic orientation (DeLancey 2001). In line with Heath's argument (Heath 1998), I stand against the extension of the "inverse" terminology to forms lacking an inverse marker, arguing that it actually undermines the usefulness of such a term. The Emerillon indexation system on verbs is then a plain hierarchical system. 


\section{Characterising the alignment system of Emerillon}

Whatever the definition of alignment (either the way the arguments of a transitive predicate align with the unique argument of an intransitive verb, or the way grammatical relations map with grammatical roles), the hierarchical indexation system presented above can not be reduced to alignment. The relative position of arguments on the hierarchies does not assign them their grammatical roles. The system focuses on the relative saliency of the participants.

"We are used to thinking of verb agreement as tied to grammatical relations: a common claim about the typology of verb agreement is that if a language has verb agreement it will index the subject; some languages index both subject and object, and a rare handful index only objects. However, there are languages in which indexation of arguments in the verb reflects not grammatical relations, but the person hierarchy. In these languages a verb will always agree with a SAP argument, regardless of its grammatical role." (DeLancey 2001)

This is where I want to draw a neat distinction between hierarchical indexation and hierarchical alignment. If we consider hierarchical indexation systems, they just rule access to inflectional slots. Within the same languages, alignment can still be marked in other morphosyntactic domains. This explains why hierarchical systems can co-occur with other alignment patterns, as Nichols states it: "most hierarchical languages also have an identifiable accusative, neutral, or stative-active component. We may speak of hierarchical languages, like stative-active languages, as admitting various base alignments, at least in theory." (Nichols 1992: 68). Now as far as hierarchical alignment is concerned, we deal with languages where the hierarchies constrain the assignment of grammatical relations to $\mathrm{S}, \mathrm{A}$ and $\mathrm{P}$. A notable case is when the indexability hierarchy governs the access to syntactic function, as in Kiowa (Zúñiga 2006:65).

For this reason, my position is that a system such as the Emerillon one is to be simply seen as an indexation system rather than as an alignment type. The scope of hierarchies does not go beyond the selection of the argument to be encoded on the transitive verb. It does not creep in the access to grammatical roles and even less so to grammatical relations. Consequently, the Emerillon alignment type has to be determined separately from its indexation system type. Characterization of the alignment type of a specific language should take into account several parameters, including indexation, but also case, constituent order and syntax, since different types of align- 
ment may co-occur in a language, depending on the parameter and/or the specific construction observed. Since arguments in Emerillon are not marked for case and their order is relatively flexible, the argumentation will be based on the indexation pattern described above and on syntactic phenomena.

Even though the Emerillon indexation system is based upon the notion of hierarchies, grammatical roles are not completely excluded from it. Remember that if the selection of the argument to be indexed on the transitive verb depends on its position on the hierarchies, yet the morphological paradigms of the indexes correlate with grammatical roles. Set I encodes A, while Set II encodes P. Since the unique argument of an intransitive verb is also encoded with Set I, it aligns with the A argument of a transitive verb. This forms a nominative-accusative system, where $\mathrm{S}$ and $\mathrm{A}$ are encoded likewise, and differently from $P$.

Syntactic phenomena confirm the subject category postulated when looking at the distribution of the morphological paradigms. Some agreement and coreference patterns are indeed associated with a subject category comprising $\mathrm{S}$ of intransitive verbs and $\mathrm{A}$ of transitive verbs. Two examples are given below. First, the plural clitic $-(o) \eta$ agrees exclusively with the unique argument of a verbal intransitive predicate (19) and the A argument of a transitive verb (20), but not with the $\mathrm{P}$ argument of a transitive verb (21). Within the Tupi-Guarani family, this criterion is specific to Emerillon, since the family does not offer a unified way of marking number.

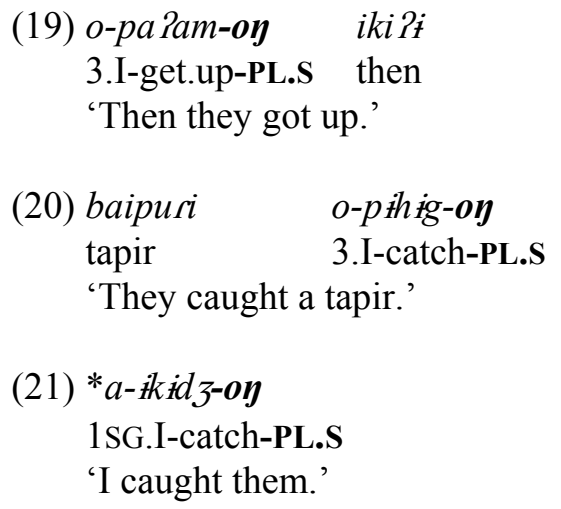

Second, a criterion widely used by tupi-guaranists to define the subject grammatical relation is the use of an $o$ - index for third person possessors or 
objects of postpositions specifically triggered by coreference with the subject, be it of an intransitive (22) or a transitive verb (23).

(22) o-ho o-wíkoti

3.I-go 3.COREF-mother-to

'He is going to his (own) mother.'

(23) bokal-a-pe o-akay o-mõde

jar-REF-in 3.COREF-head 3.I-put

'He put his (own) head in the jar.'

As a consequence, the coreferential index $o$ - is in opposition with the Set II (i.e. non-coreferential) third person marker $i$-, both as a possessor (compare examples (23) and (24)) and as an object of postposition (compare (25) and (26)).

(24) $\boldsymbol{i}$-(d3)akay zawar o-wur

3.II-head dog 3.I-go.up

'The dog went up on his head.'

(25) o-ipun $\quad \boldsymbol{O}-w \dot{w} b$

3.I-put 3.COREF-under

'She put it under herself.'

(26) o-bowig i-wib

3.I-put.firewood 3.II-under

'They put more firewood under it.'

In brief, person indexes paradigms and syntactic patterns verify the analysis of the Emerillon alignment type as nominative-accusative. In this case, alignment is therefore completely independent of the hierarchical indexation system. Of course, in all hierarchical indexation systems, a device is necessary to disambiguate between A and P. In some languages, it is done through the existence of direct/inverse morphology. In Emerillon, this is done through the existence of two distinct person indexes sets. This is how this indexation system, though not organized so as to primarily mark such and/or such grammatical roles, yet marks grammatical roles and therefore participates in the general alignment type of the language, that is basically nominative-accusative. 


\section{Conclusion : a hierarchical indexation system}

To give a brief summary of the Emerillon person indexation system on the verbs, intransitive verbs take a Set I index, while transitive verbs allow only one person index, from Set I for their subject or from Set II for their object. The correct index is selected according to the relative position of the two arguments on both the person hierarchy $1 / 2>3$ and the grammatical roles hierarchy A $>$ P. Thus, hierarchy is the primary organizing pattern of the Emerillon agreement system. Since no morpheme can be considered to be marking direction of action (as normal or reversed, i.e. direct or inverse), the system is simply labelled hierarchical. A larger picture of the language (including syntax) shows a nominative-accusative alignment, where the A of a transitive verb aligns with the $\mathrm{S}$ of an intransitive verb. The following table sums up the characterization of indexation and alignment in Emerillon.

Table 4. Indexation and alignment in Emerillon

\begin{tabular}{|l|l|}
\hline indexation on transitive verbs & hierarchical with no direction marking \\
\hline morphological alignment & nominative-accusative \\
\hline syntactic alignment & nominative-accusative \\
\hline
\end{tabular}

It is clear from this table that out of the three possible implications of the indexability hierarchy in a language (access to marking slots, marking of direction, access to syntactic functions, cf. Zúñiga 2006: 27, out of Nichols 2002: 66), Emerillon shows only the first one: the hierarchy only serves to select the argument to be indexed on the transitive verb.

The analysis of the hierarchical indexation system of Emerillon, in comparison with other languages, leads to three theoretical assertions. First, hierarchical systems should be considered alongside major indexation systems. Second, inverse systems should be considered as a subtype of hierarchical systems more generally, rather than the other way around. And finally, indexation should be considered independent from alignment.

\section{Notes}

1. I would like to thank Francesc Queixalós, Andrej Kibrik and Scott DeLancey for their helpful remarks on initial steps of this investigation, as well as Denis Creissels and Katharina Haude for more recent discussions.

2. $s i$ - and $i$ - are realized $s e$ - and $e$ - before the vowel $i$. 
3. zo- is used on nouns, poro- on verbs to mark a generic human object 'people'.

4. The abbreviations used in this chapter are the following: I, II Set I, Set II; A most agent-like argument of a transitive clause; COMPL completive; CONT continuous; CONTRAST contrastive; COP existential copula; COREF coreferential; DEM demonstrative; DESID desiderative; EXCL exclusive; FUT future (immediate future); INCL inclusive; INDET indeterminate; INTENS intensive ; INTER interrogative; LK linker; P most patient-like argument of a transitive clause; PL plural; PL.S plural of subject; PRO pronoun; RED reduplication; REF referential; RELN relational; $\mathrm{S}$ unique argument of an intransitive clause; SG singular.

5. The Set II prefix $i$ - is actually found on some gerundives, as a residue of former absolutive marking on verbs in dependent clauses (Rose, submitted).

6. The configuration where a first person inclusive interacts with some other speech act participant (i.e. second person or first person singular), even though logically possible, is never attested in my corpus. The overt expression of such a configuration is probably dispreferred due to the overlapping of the two referents.

7. The peculiar use of the independent second person markers in $2 \rightarrow 1$ SG scenarios can probably be explained as a hypothetical residue of a Proto-TupiGuarani marker for A. Since the hierarchy in Proto-Tupi-Guarani is supposed to be $1>2>3$ (Montserrat \& Soares 1983, Jensen 1998), in the same $2 \rightarrow 1$ scenario, the first person $\mathrm{P}$, being higher in the hierarchy, is cliticized before the verb and the second person A is then expressed with an independent pronoun following the verb. For a detailed account of this diachronic hypothesis, see Rose (2003b and 2007).

8. This chapter deals with person indexation on verbs only. However, in a study also taking into account nominal predicates (including among them descriptive words), the system could be considered as displaying split intransitivity, since different types of intransitive predicates take different person marking. Intransitive verbs take Set I prefixes while nominal predicates take Set II prefixes. In the analysis of Tupi-Guarani languages where descriptive words are classified as verbs (such as Kakumasu 1986, Leite 1990, Jensen 1998, Seki 2000), the split intransitivity analysis holds within the verbal indexation system. For a detailed account of the debate on which part of speech do the descriptive words belong to, see Meira (2006).

9. The author just mentions that the local scenario where a first person acts on a second person is traditionally described as using so-called portmanteau morphemes (considered to belong to a separate paradigm called Set IV, see for example Jensen 1998: 522). However, it would be easy to integrate the other local scenario participates in the putative direct/inverse system : when a second person acts on a first person (as in (10) from Tupinambá), the first person $P$ is marked on the verb with a Set II clitic. This scenario illustrates both the inverse function and the so-called inverse morphology. 


\section{References}

Bickel, Balthasar and Johanna Nichols

2007 Inflectional morphology. In Language Typology and Syntactic Description. Vol. III; Timothy Shopen (ed.), 169-240. Cambridge: Cambridge University Press.

Brown, Penelope and Stephen Levinson

1987 Politeness. Cambridge: Cambridge University Press.

Comrie, Bernard

1981 Language Universals and Linguistic Typology. Oxford: Basil Blackwell.

Couchili, Ti'iwan, Didier Maurel and Francesc Queixalós

2002 Classes de lexèmes en émérillon. Amerindia 26/27: 173-208.

DeLancey, Scott

no date Topicality, and the Inverse. ms.

http://www.uoregon.edu/ delancey/papers/inverse.html

DeLancey, Scott

1981 An interpretation of split ergativity and related patterns. Language 57: 626-657.

DeLancey, Scott

2001 Lectures on Functional Syntax. Class given at the LSA Summer Institute, University of California at Santa Barbara. http://www.uoregon.edu/ delancey/sb/fs.html

Gildea, Spike

1994 Semantic and pragmatic inverse : 'inverse alignment' and 'inverse voice' in Carib of Surinam. In Voice and Inversion; Talmy Givón (ed.), 187-230. Amsterdam/Philadelphia: John Benjamin's.

Givón, Talmy

1994 The pragmatics of de-transitive voice: functional and typological aspects of inversion. In Voice and Inversion; Talmy Givón (ed.), 344. Amsterdam/Philadelphia: John Benjamin's.

Harrison, Carl

1984 Verb prominence, verb initialness, ergativity and typological disharmony in Guajajara. In Handbook of Amazonian Languages. Vol. I; Desmond Derbyshire and Geoffrey Pullum (eds.), 407-439. Berlin: Mouton de Gruyter.

Heath, Jeffrey

1998 Pragmatic skewing in 1-2 pronominal combinations in Native American Languages. International Journal of American Linguistics 64(2): 83-104.

Jensen, Cheryl

1990 Cross-referencing changes in some Tupí-Guaraní languages. In Amazonian Linguistics, Studies in Lowland South American Lan- 
guages; Doris Payne (ed.), 117-158. Austin: University of Texas Press.

Jensen, Cheryl

1998 Comparative Tupí-Guaraní Morpho-syntax. In Handbook of Amazonian Languages. Vol. IV; Desmond Derbyshire and Geoffrey Pullum (eds.), 489-619. Berlin: Mouton de Gruyter.

Jensen, Cheryl

1999 Tupí-Guaraní. In The Amazonian Languages; R. M. W. Dixon and Alexandra Aikhenvald (eds.), 125-163. Cambridge: Cambridge University Press.

Kakumasu, James

1986 Urubu-Kaapor. In Handbook of Amazonian Languages. Vol. I; Desmond Derbyshire and Geoffrey Pullum (eds.), 326-403. Berlin: Mouton de Gruyter.

Klaiman, M.H.

1991 Grammatical Voice. (Cambridge Studies in Linguistics 59) Cambridge: Cambridge University Press.

Leite, Yonne

1990 Para uma tipologia ativa do Tapirapé, os clíticos referenciais de pessoa. Cadernos de Estudos Linguisticos 18: 37-56.

Meira, Sergio

2006 Mawe Stative Verbs and Predicate Possession. In Guarani y MawetíTupi-Guaraní. Estudios Históricos y Descriptivos sobre una Familia Lingüistica de América del Sur; Wolf Dietrich and Haralambos Symeonidis (eds.), 47-68. Berlin: LIT Verlag.

Montserrat, Ruth \& Marília Faco Soares

1983 Hierarquia referencial em línguas Tupi. Ensaios de Lingüística 9: 164-187.

Nichols, Johanna

1992 Linguistic Diversity in Space and Time. Chicago/London: University of Chicago Press.

Payne, Doris

1994 The Tupí-Guaraní inverse. In Voice: Form and Function; Barbara Fox \& Paul Hopper (eds.), 313-340. (Typological Studies in Language 27). Amsterdam/Philadelphia: John Benjamins.

Payne, Thomas

1997 Describing Morpho-syntax: a Guide for Field Linguists. Cambridge:

Queixalós, Francesc

Cambridge University Press.

2001 Le suffixe référentiant en émérillon. In Des Noms et des Verbes en Tupi-Guarani: État de la Question; Francesc Queixalós (ed.), 115132. (LINCOM Studies in Native American Languages 37) München: Lincom Europa. 
Rodrigues, Aryon Dall'Igna

1984-1985 Relações internas na família lingüística Tupí-Guaraní. Revista de Antropologia 27/28: 33-53.

Rodrigues, Aryon Dall'Igna

1990 You and I = neither you nor I: the personal system of Tupinambá. In Amazonian Linguistics, Studies in Lowland South American Languages; Doris Payne (ed.). Austin: University of Texas Press.

Rose, Françoise

2003a Morphosyntaxe de l'Émérillon. Une Langue Tupi-Guarani de Guyane Française. $\mathrm{PhD}$ diss., Linguistics Department, Université Lumière Lyon II, France.

Rose, Françoise

2003b Le marquage des personnes en émérillon (tupi-guarani) : un système d'accord hiérarchique. Faits de Langues 21: 107-120.

Rose, Françoise

2007 As particularidades da língua Emerillon entre as línguas TupíGuaraní: O caso da marcação de pessoa. In Linguas e Culturas Tupí; Aryon Rodrigues and Ana Suelly Cabral (eds.), 325-332. Campinas: Curt Nimuendajú.

Rose, Françoise submitted The origins of serialization : the case of Emerillon.

Rose, Françoise to appear Grammaire de l'Émérillon (teko), Langue Tupi-Guarani de Guyane Française. (Langues et Sociétés d'Amérique traditionnelle). Louvain: Peeters.

Seki, Lucy

1990 Kamaiurá (Tupí-Guaraní) as an active-stative language. In Amazonian Linguistics, Studies in Lowland South American Languages; Doris Payne (ed.). Austin: University of Texas Press.

Siewierska, Anna

2004 Person. (Cambridge Textbooks in Linguistics) Cambridge: Cambridge University Press.

Silverstein, Michael

1976 Hierarchy of features and ergativity. In Grammatical Categories in Australian Languages; R.M.W. Dixon (ed.), 112-171. Canberra: Australian Institute of Aboriginal Studies.

Zúñiga, Fernando

2006 Deixis and Alignment. Inverse Systems in Indigenous Languages of the Americas. (Typological Studies in Language 70) Amsterdam/Philadelphia: John Benjamins. 